\title{
Impact of telephone monitoring on cancer patients undergoing esophagectomy and gastrectomy*
}

\author{
Impacto do monitoramento telefônico em pacientes oncológicos \\ submetidos a esofagectomia e gastrectomia \\ Impacto del monitoreo telefónico en pacientes oncológicos \\ sometidos a esofagectomía y gastrectomía
}

How to cite this article:

Oliveira DSS, Ribeiro Junior U, Sartório NA, Dias AR, Takeda FR, Cecconello I. Impact of telephone monitoring on cancer patients undergoing esophagectomy and gastrectomy. Rev Esc Enferm USP. 2021;55:e03679. doi: https://doi.org/10.1590/S1980-220X2019023003679

\section{Daniele da Silva Salgado Oliveira ${ }^{1}$ \\ Ulysses Ribeiro Junior ${ }^{1}$ \\ Natalia de Araújo Sartório ${ }^{1}$ \\ André Roncon Dias ${ }^{1}$ \\ Flávio Roberto Takeda ${ }^{1}$ \\ Ivan Cecconello ${ }^{1}$}

* Extracted from the dissertation: "Impacto do monitoramento telefônico de enfermagem nos sintomas e qualidade de vida de pacientes no pós-operatório de câncer de esôfago e estômago", Faculdade de Medicina, Universidade de São Paulo, 2019.

${ }^{1}$ Universidade de São Paulo, Faculdade de Medicina, Hospital das Clínicas, Instituto do Câncer do Estado de São Paulo, São Paulo, SP, Brazil.

\section{ABSTRACT}

Objective: To evaluate telephone monitoring for symptoms, quality of life, distress, admissions to the emergency center and the satisfaction of cancer patients undergoing esophagectomy and gastrectomy. Method: Randomized controlled study in two groups, carried out at the Cancer Institute of the State of Sao Paulo; the intervention group received telephone monitoring for four moments after the surgery, while the control group received only institutional care. Results: Of the 81 patients evaluated, the domain most affected by quality of life was social relationships domain. Distress had no significant difference between groups and moments. In both groups, admissions to the emergency center were similar $(p=0.539)$. Pain was the most reported symptom in telephone monitoring. There was statistical significance regarding patient satisfaction with monitoring $(\mathrm{p}=0.002)$. Conclusion: Telephone monitoring provided greater patient satisfaction in the intervention group, demonstrating the real impact of this process on the care of cancer patients.

\section{DESCRIPTORS}

Neoplasms; Gastrectomy; Esophagectomy; Telemonitoring; Quality of Life; Oncology Nursing. 


\section{INTRODUCTION}

Telephone has been used for several purposes in medicine, from screening to chronic patients follow-up; in primary health care and health counseling, resulting in reduced waiting times for consultations, reduced cost of transportation for patients, in addition to improving professional contact ${ }^{(1)}$.

Monitoring can be aimed at patient adherence to treatment, in addition to being an important tool in their self-management. Thus, nurses are responsible to establish education strategies, leading to safety, promoting clear and effective communication, aiming to improve treatment and home care after a surgical procedure ${ }^{(2)}$.

Surgery is one of the therapeutic alternatives for the treatment of esophageal and stomach tumors. In the first postoperative months, patients may experience undesirable symptoms, which can impair quality of life when compared to the preoperative condition. Telephone monitoring can be used for the development of psychoeducational interventions, in the monitoring and control of symptoms, being a resource that expands the action of the health professional, with targeted care at each moment of cancer treatment ${ }^{(3-4)}$.

The evaluation of the Quality of Life (QL) of cancer patients is an important indicator of the patients' response to the disease and treatment. The concept of quality of life has been widely used currently and the interest in measuring it in relation to health care has increased in recent years ${ }^{(5)}$.

Even today, cancer is a disease whose meaning is threatening to most people, as it is associated to the risk of death, and requires, from the affected individuals, strength, and creativity to bear changes in their lifestyle. Thus, it is necessary to evaluate the distress, defined as an unpleasant and multifactorial emotional experience, which interferes with the ability to deal with the disease, its physical changes, symptoms and treatment. Therefore, it is essential to identify the symptoms of stress in each stage of oncological experiences ${ }^{(6)}$.

Pain assessment is a common phenomenon, felt by human beings and expressed in different ways. Important advances have occurred in recent years in relation to pain assessment, among them was the standardization of pain as the fifth vital $\operatorname{sign}^{(7)}$.

The objectives of this study were to evaluate the impact of active monitoring and verbal nursing guidance by telephone on the symptoms and quality of life of patients undergoing outpatient care, who underwent surgical resections of the esophagus and stomach. Patients' symptomatology, quality of life, distress and pain were assessed, as well as the admissions to the emergency department and patient satisfaction.

\section{METHOD}

\section{STUdP DESIGN}

A prospective randomized controlled study was conducted.

\section{SCENARIO}

It was carried out at Octavio Frias de Oliveira Cancer Institute of the State of São Paulo (ICESP) from May 2015 to December 2017, totaling 83 patients who agreed to participate in the study during the collection period; however, two patients were excluded.

\section{SeleCtION CRITERIA}

Initially, patients with a diagnosis of esophageal and stomach cancer with a surgical treatment proposal, admitted to ICESP and who agreed to participate in the study were considered eligible. The patients were randomized into two groups: the control one, group in which telephone monitoring or nursing intervention was not carried out, receiving only institutional care (Hello Nurse - Alô Enfermeiro); and the intervention one, group in which, according to part of the study, active monitoring or nursing intervention was carried out at pre-established moments. The Hello Nurse program at ICESP is a telephone monitoring center, 24 hours a day, in which the patient contacts the nursing team to clarify questions, at a distance, regarding the clinical or surgical oncological treatment, aiming at providing non-pharmacological management interventions for the signs and symptoms reported by patients.

\section{Data collection}

The patients in the intervention group were informed that, after hospital discharge, telephone contact would be made in the following moments: $\mathbf{1}^{\text {st }}$ telephone contact After five days of hospital discharge or on the first business day after the fifth day; $2^{\text {nd }}$ telephone contact - after 60 days of hospital discharge or on the first business day after; $\mathbf{3}^{\text {rd }}$ telephone contact - After 120 days (4 months) of hospital discharge or on the first business day after; $4^{\text {th }}$ telephone contact - After 270 days (9 months) of hospital discharge or on the first business day after. All patients were instructed that, on medical returns with the surgical team, the same questionnaires would be applied to assess quality of life, stress and pain, according to the moments described: Moment 01 (T0) - Before the surgical procedure, after delivery of the surgical kit; Moment 02 (T1) - At the first consultation with the surgeon, after surgical treatment (approximately 20 days); Moment 03 (T2) - In the second consultation with the surgeon, after surgical treatment (approximately 3 months); Moment 04 (T3): In the third consultation with the surgeon, after surgical treatment (approximately 6 months); Moment 05 (T4) - In the fourth consultation with the surgeon, after surgical treatment (approximately 1 year).

The instruments used for data collection were: Quality of Life Questionnaire - European Organization for Research and Treatment of Cancer (EORTC QLQC30) ${ }^{(8)}$, which is multidimensional and self-administered with the objective of quantitatively assessing the quality of life in cancer patients. This instrument has assessment scales: five functional subscales (FE), which are physical capacity (corresponds to questions 1 to 5), role performance (corresponds to questions 6 and 7), cognitive (questions 20 and 25 ), emotional (corresponds to questions 21 to 24) and social (corresponds to questions 26 and 27); three symptom scales (SE), such as fatigue (questions 10,12 and 18), nausea or vomiting (questions 14 and 15) and pain (corresponds to questions 
9 and 19); items that assess symptoms, commonly reported by cancer patients, such as dyspnea (question 8), loss of appetite (question 13), insomnia (question 11), constipation and diarrhea (corresponds to questions 16 and 17); scale for assessing the financial impact of the disease and treatment, corresponding to question 28; and finally the global health scale (GHS), which focuses on quality of life aspects, corresponding to questions 29 and 30 . For each item, the patient chooses answers with the following scores: 1- no, 2- little, 3 - moderately or 4 - a lot. In questions 29 and 30 there is an increasing scale from 1 (poor health or quality of life) to 7 (excellent health and quality of life) ${ }^{(8-9)}$.

The distress thermometer was also used, which consists of two instruments: one that evaluates the level of distress (through the figure of a thermometer), from 0 (no distress) to 10 (extreme distress), in which they are classified from 0 to 4 (mild distress), from 5 to 7 (experiences of distress that affects quality of life) and 8 to 10 (experience of high distress that can cause difficulties in daily activities); the second instrument has 35 items, aimed at recognizing the possible causes of distress ${ }^{(6,10)}$.

The applied pain scale was the verbal numeric, which is used for communicative patients without cognitive impairment. This scale has an assigned value from 0 (no pain) to 10 (worst imaginable pain). There is a correspondence between the verbal numerical and the verbal descriptive scales, which comprises different scores: 0 (no pain), 1 to 3 (mild pain), 4 to 6 (moderate pain) and $\geq 7$ (severe/unbearable pain) ${ }^{(11-12)}$.

Patient satisfaction was evaluated using a quantitative instrument designed to assess satisfaction with the institutional service and telephone contact made during the study in postoperative care, as well as satisfaction with the institution. Scores from 1 to 5 were assigned to each question, 1 (minimum satisfaction), 2 (poor satisfaction), 3 (regular satisfaction), 4 (good satisfaction) and 5 (excellent satisfaction).

\section{Data ANALYSIS}

The data analysis process started with descriptive analysis, with the inclusion of the Confidence Interval for the proportion (95\% CI). When necessary, analytical methods, such as bivariate analysis, were used in the contingency table using Fischer's Exact Test for qualitative variables. A bidirectional $\alpha$ of 0.05 was considered.

\section{ETHICAL ASPECTS}

After approval by the Research Ethics Committee of the Cancer Institute of the State of São Paulo (NP 734/14 of October 5,2014) and the Research Ethics Committee of the Faculty of Medicine at the Universidade de São Paulo, under Opinion No. 019, of February 11, 2015, patients diagnosed with esophageal or stomach cancer with indication for surgical treatment were prospectively analyzed. Participants who accepted to participate in the research signed the Informed Consent form (ICF) in two copies. The development of the research followed the Regulatory Norms for Research involving human beings, as established by the resolution of the National Health Council No. 466/2012.

\section{RESULTS}

A total of 83 patients were selected for the study, with two patients being excluded: one of them due to the withdrawal of the study consent by the patient, and the other one due to the change in the proposed treatment. The data of 81 patients were assessed regardless of whether they had completed the follow-up proposed by the study. Of these, 40 patients were randomized to the control group and 41 to the intervention group. There was an adequate distribution between the two groups for the variables analyzed, as shown in Table 1.

Table 1 - Descriptive analysis of qualitative variables, including absolute and relative frequencies and 95\% confidence interval (95\% CI) between individuals in the control and intervention groups - ICESP, São Paulo, Brazil, 2015-2017.

\begin{tabular}{|c|c|c|c|c|c|c|c|c|}
\hline & \multicolumn{4}{|c|}{ Control } & \multicolumn{4}{|c|}{ Intervention } \\
\hline & \multirow{2}{*}{$\mathbf{N}$} & \multirow{2}{*}{$\%$} & \multicolumn{2}{|c|}{$95 \% \mathrm{Cl}$} & \multirow{2}{*}{$\mathbf{n}$} & \multirow{2}{*}{$\%$} & \multicolumn{2}{|c|}{ IC95\% } \\
\hline & & & Lower & Upper & & & Lower & Upper \\
\hline \multicolumn{9}{|l|}{ Gender } \\
\hline Male & 27 & $67.5 \%$ & $52.2 \%$ & $80.4 \%$ & 29 & $70.7 \%$ & $55.8 \%$ & $82.9 \%$ \\
\hline Female & 13 & $32.5 \%$ & $19.6 \%$ & $47.8 \%$ & 12 & $29.3 \%$ & $17.1 \%$ & $44.2 \%$ \\
\hline \multicolumn{9}{|l|}{ Diagnostic } \\
\hline Stomach cancer & 24 & $60.0 \%$ & $44.6 \%$ & $74.1 \%$ & 27 & $65.9 \%$ & $50.7 \%$ & $78.9 \%$ \\
\hline Esophagus cancer & 16 & $40.0 \%$ & $25.9 \%$ & $55.4 \%$ & 14 & $34.1 \%$ & $21.1 \%$ & $49.3 \%$ \\
\hline \multicolumn{9}{|l|}{ Education } \\
\hline Funcional illiterate or not & 3 & $7.5 \%$ & $2.2 \%$ & $18.7 \%$ & 5 & $12.2 \%$ & $4.8 \%$ & $24.7 \%$ \\
\hline Incomplete primary education & 15 & $37.5 \%$ & $23.8 \%$ & $52.9 \%$ & 16 & $39.0 \%$ & $25.3 \%$ & $54.3 \%$ \\
\hline Complete primary education & 11 & $27.5 \%$ & $15.6 \%$ & $42.5 \%$ & 9 & $22.0 \%$ & $11.5 \%$ & $36.2 \%$ \\
\hline Incomplete secundary education & 1 & $2.5 \%$ & $0.3 \%$ & $11.1 \%$ & 3 & $7.3 \%$ & $2.1 \%$ & $18.3 \%$ \\
\hline Complete secundary education & 6 & $15.0 \%$ & $6.5 \%$ & $28.3 \%$ & 4 & $9.8 \%$ & $3.4 \%$ & $21.5 \%$ \\
\hline
\end{tabular}




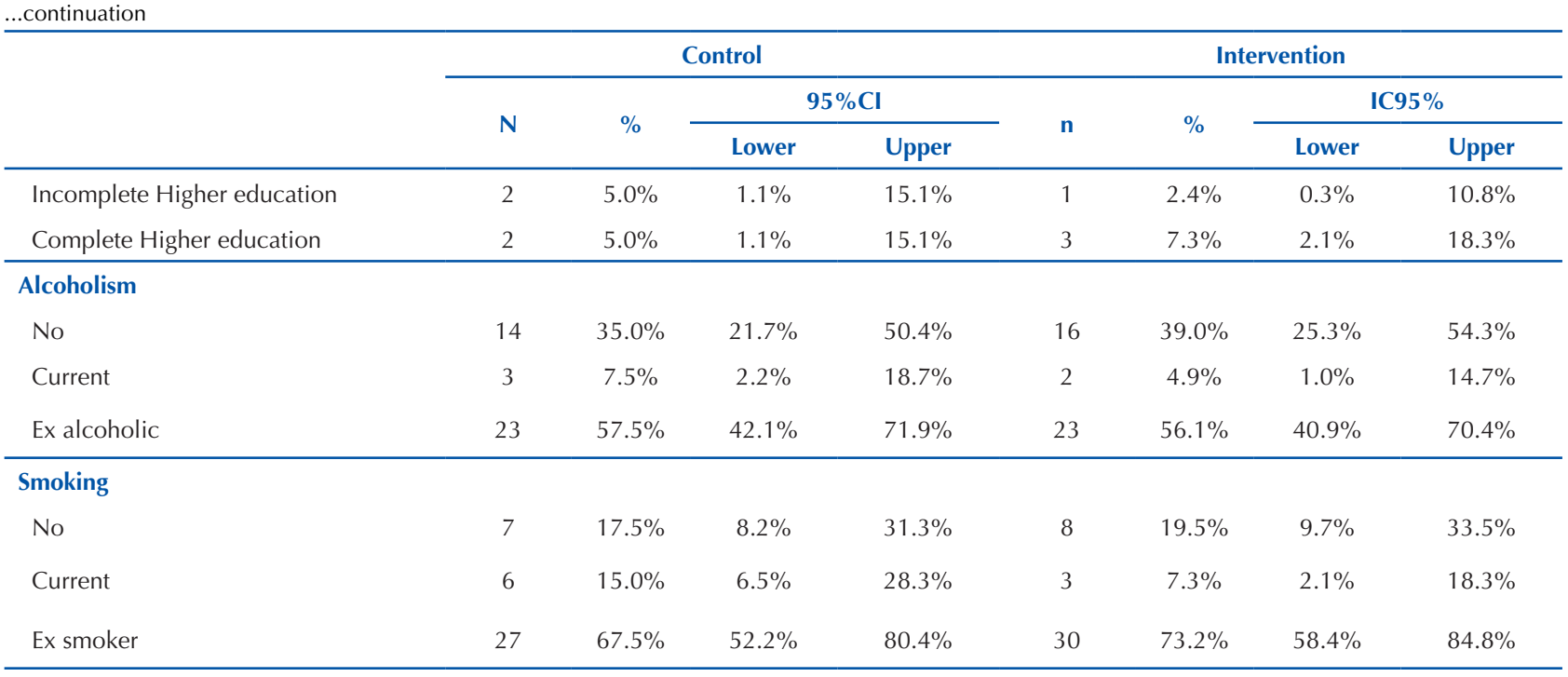

Most patients in relative frequency finished the follow-up as proposed in the research, $57.5 \%$ (95\% CI $42.1 \%$ - 71.9\%) in the control group and 68.3\% (95\% CI 53.2\% - 80.9\%) in the intervention group. During follow-up, $22.5 \%$ of patients in the control group and $12.2 \%$ in the intervention group missed the study follow-up. Regarding death, $20.0 \%$ of patients in the control group and $19.5 \%$ in the intervention group died at some point in the study.

As for the EORTC QLQC30 quality of life questionnaire, when assessing the role/routine performance between groups and moments, $75 \%$ of patients had a score of 100.0 at moments $\mathrm{T} 0$ and T 4 in both groups, and at least $25 \%$ of patients in the control group had a lower score (33.3) at moments T1 and T3. The assessment of cognitive function in at least $75 \%$ of patients in both groups and at all moments had a score equivalent to 100.0, showing a better cognitive performance in the study population. However, at least $25 \%$ of patients in the control group had the lowest score (50.0) at T1 and T2. In the emotional function in both groups at moments $\mathrm{T} 0, \mathrm{~T} 2$ and $\mathrm{T} 4$, at least $50 \%$ of the patients had homogeneous scores $(75.0,75.0$ and 83.3 respectively), with no serious emotional functions that could affect the quality of life. However, at least $25 \%$ of patients had the lowest score (41.7) in the control group, at moment T2. Regarding social function, at least $75 \%$ of patients in both groups and at all moments had a score of 100.0, in which physical condition and treatment did not interfere with social activities. Still, at T2 in the control group, at least $25 \%$ of patients had a lower score of 33.3, which could cause physical condition and treatment to interfere with social activities. In this evaluation, there was no statistical significance between the groups and the moments $(\mathrm{p}=0.698)$.

According to the symptom scales, the symptoms of nausea and vomiting occurred in at least $50 \%$ of patients in both groups and at all moments. Regarding insomnia, at least $50 \%$ of the patients in the control group at moments T2 and T3 did not have insomnia, but at least $75 \%$ had a higher score (66.7) in both groups at moments T0 and T1 and the group control at T2. In the intervention group, at this moment (T2), at least 75\% had insomnia (score of 83.3).
When assessing loss of appetite in the control group at T1, at least $75 \%$ of patients had a higher score (100.0), which may be related to an intense loss of appetite. At moment $\mathrm{T} 4$, in both groups, at least $50 \%$ of patients had preserved appetite, with a score of zero (0.0). Regarding constipation, at least $50 \%$ of the patients in the control group, at moments T0, T2, T3 and T4, did not have constipation, but at T1, at least $75 \%$ of patients reported a higher score (100.0), which may correspond to an important constipation.

In the assessment of global health and quality of life (Figure 1), it was observed that at least $75 \%$ of the patients in the control group at moments $\mathrm{T} 0$ and $\mathrm{T} 4 \mathrm{had}$ a score of 100.0, and in the intervention group this occurred at moment T4 with excellent physical condition and quality of life. Both groups, at T1, had $25 \%$ of patients with a lower score (50.0), impairing physical condition and quality of life.

Regarding the level of distress reported by patients, it is clear that at all moments at least $50 \%$ of patients in both groups reported level 2 distress (mild distress), and there was no statistical significance between the groups studied and the moments of application of this questionnaire $(\mathrm{p}=0.414)$.

Among the main possible causes of distress, one can mention emotional problems as the most prevalent reported by patients in the control and intervention groups in the preoperative period. Regarding physical problems, the most reported were difficulty sleeping, followed by fatigue. The problems less referred to as cause of distress were physical ones, such as mucositis and fever. Religious involvement was also one of the problems cited which does not interfere with distress.

With regard to pain assessment on an ordinal qualitative scale, in the first moment after surgery (T1), 42.1\% (95\% CI $27.5 \%-57.9 \%$ ) of the patients in the control group did not have pain, and this same percentage (42.1\%) reported mild pain. In the intervention group, $41.7 \%$ (95\% CI $26.7 \%$ - 57.9\%) had mild pain. Regarding severe/unbearable pain, no patient $(0 \%)$ in the control group reported having this level of pain, whereas in the intervention group, 2.8\% (95\% CI $0.3 \%-12.3 \%)$ had severe/unbearable pain. At the last moment of the evaluation, $67.9 \%$ (95\% CI $49.5 \%-82.8 \%$ ) 
of the patients in the intervention group did not have pain, and in the control group the absence of pain occurred in $60.9 \%$ (95\% CI 40.6\% - 78.6\%) of the patients. Among these assessments, there was no statistical significance between the groups and the moments.

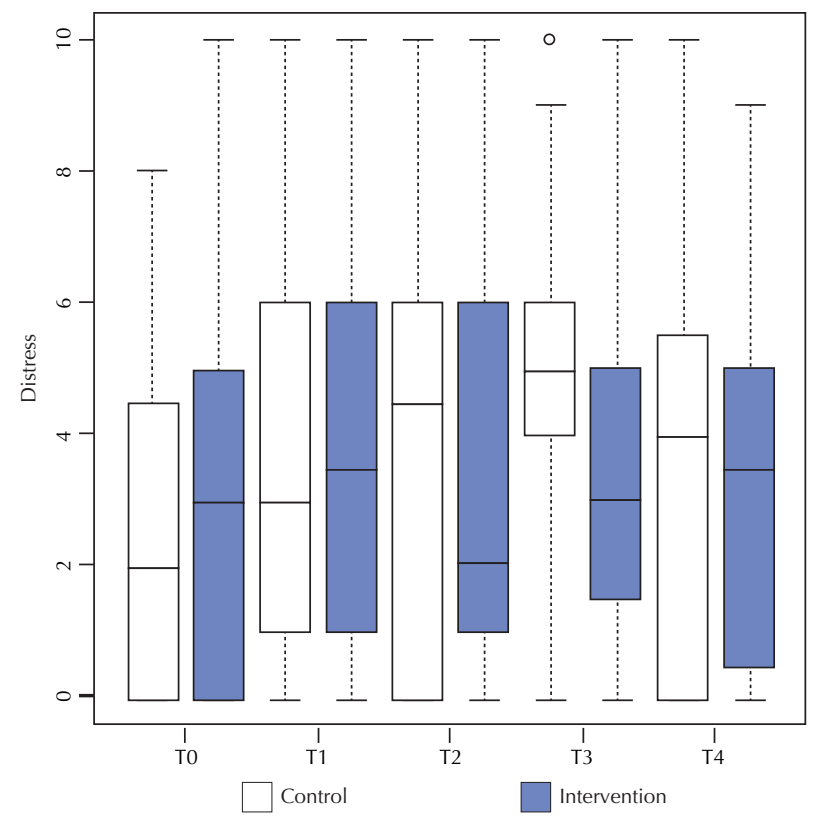

p-value group $*$ time $=0.414$.

Figure 1 - Distribution of distress between individuals in the control and intervention groups and moments - ICESP, São Paulo, Brazil, 2015-2017.
As for the analysis regarding the number of patients' visits to the Oncological Intercurrence Care Center (OICC) during the study follow-up, it was observed that, in both groups, the number of patients admitted was similar (median=1), with a total of 25 patients admitted to OICC in the control group and 23 patients in the intervention group, $(\mathrm{p}=0.539)$.

In the analysis of nursing interventions for patients randomized to this group, their symptoms after the surgical procedure were evaluated and the interventions were performed according to each symptom presented. In all four moments, it was observed that the symptom most reported by patients was pain, in several parts of the body. At the first contact, $52.6 \%$ (95\% CI 37.1\% - 67.8\%) of the patients reported pain, followed by $44.4 \%$ (95\% CI 29.2\% - 60.6\%) at the second contact, $48.4 \%(95 \%$ CI $31.6 \%-65.5 \%)$ in the third contact and $34.5 \%$ (95\% CI 19.3\% - 52.6\%) in the fourth contact. The other symptoms presented at the first contact were diarrhea, followed by nausea, vomiting and constipation. In the second and third contacts, after pain, lack of appetite was the most reported symptom, while in the fourth moment, patients referred nausea as one of the most common symptoms after pain, as well as vomiting and diarrhea.

The evaluation between the groups in relation to the degree of satisfaction for the care by the active monitoring via telephone showed that, in the intervention group, $87.5 \%$ (95\% CI 73.0\% - 95.6\%) of the patients evaluated this service as excellent in relation to $53.3 \%$ (95\% CI $29.4 \%-76.1 \%$ ) of patients in the control group $(\mathrm{p}=0.002)$. (Table 2$)$

Table 2 - Distribution of satisfaction factors including absolute and relative frequencies and 95\% confidence interval (95\% CI) among individuals in the control and intervention groups - ICESP, São Paulo, Brazil, 2015-2017.

\begin{tabular}{|c|c|c|c|c|c|c|c|c|c|}
\hline & \multicolumn{4}{|c|}{ CONTROL GROUP } & \multicolumn{4}{|c|}{ INTERVENTION GROUP } & \multirow{3}{*}{ p-value* } \\
\hline & \multirow{2}{*}{$\mathbf{N}$} & \multirow{2}{*}{$\%$} & \multicolumn{2}{|c|}{ Confidencec Interval } & \multirow{2}{*}{$\mathbf{N}$} & \multirow{2}{*}{$\%$} & \multicolumn{2}{|c|}{ Confidencec Interval } & \\
\hline & & & Lower & Upper & & & Lower & Upper & \\
\hline \multicolumn{10}{|l|}{ Successful contact } \\
\hline No & 9 & $37.5 \%$ & $20.4 \%$ & $57.4 \%$ & 2 & $5.9 \%$ & $1.2 \%$ & $17.6 \%$ & \multirow{2}{*}{0.004} \\
\hline Yes & 15 & $62.5 \%$ & $42.6 \%$ & $79.6 \%$ & 32 & $94.1 \%$ & $82.4 \%$ & $98.8 \%$ & \\
\hline \multicolumn{10}{|c|}{ Satisfaction - "Hello Nurse" } \\
\hline Good & 2 & $13.3 \%$ & $2.9 \%$ & $36.3 \%$ & 4 & $12.5 \%$ & $4.4 \%$ & $27.0 \%$ & \multirow{3}{*}{0.002} \\
\hline Excellent & 8 & $53.3 \%$ & $29.4 \%$ & $76.1 \%$ & 28 & $87.5 \%$ & $73.0 \%$ & $95.6 \%$ & \\
\hline Never used & 5 & $33.3 \%$ & $14.0 \%$ & $58.4 \%$ & 0 & $0.0 \%$ & & & \\
\hline \multicolumn{10}{|c|}{ Impact of phone calls*** } \\
\hline No & & & & & 0 & $0.0 \%$ & & & \multirow{3}{*}{-} \\
\hline Yes & & & & & 30 & $93.8 \%$ & $81.4 \%$ & $98.7 \%$ & \\
\hline Did not report & & & & & 2 & $6.3 \%$ & $1.3 \%$ & $18.6 \%$ & \\
\hline \multicolumn{10}{|c|}{ Patient or Family member**** } \\
\hline Family member & 1 & $6.7 \%$ & $0.7 \%$ & $27.2 \%$ & 10 & $31.3 \%$ & $17.3 \%$ & $48.4 \%$ & \multirow{2}{*}{0.063} \\
\hline Patient & 14 & $93.3 \%$ & $72.8 \%$ & $99.3 \%$ & 22 & $68.8 \%$ & $51.6 \%$ & $82.7 \%$ & \\
\hline
\end{tabular}

*Fischer's exact test

**From 1 to 5, what grade would you give to the "Hello Nurse" service? (1 to 5)

***Did the calls we made to your home help with post-operative care?

*****valuation with patient or Family member 


\section{DISCUSSION}

Telephone follow-up allows continuity of post-operative care at the time of hospital discharge, offering education and guidance to patients according to their needs ${ }^{(13)}$. The use of the telephone is one of the possibilities of telemedicine, emerging as an important strategy in assisting people with chronic illness ${ }^{(14)}$.

In order to obtain efficiency in the use of telephone monitoring, it is necessary to have some skills, such as empathy; listening ability; self-awareness about their own precepts, ability to transmit information clearly and objectively, as well as the ability to adapt information, consideration of patients' particularities and concerns, and guide possible intervention in each case ${ }^{(1)}$.

In this study, one sought to evaluate the symptoms presented after the surgical procedure for patients randomized to the intervention group, in which it was possible to notice that pain was the most prevalent symptom in all telephone contacts, followed by diarrhea, lack of appetite, nausea and vomiting. In a study on telephone follow-up after hospital discharge with onco-hematological patients, it was demonstrated that the most common symptoms presented at home were nausea, mucositis, constipation and fatigue, and that their knowledge and management through the follow-up is the differential to make them less intense and even possible to be controlled by the patients themselves, promoting selfcare and better quality of life ${ }^{(15)}$.

In this study, regarding quality of life, it can be seen that the role performance and social function in the control group, in the first and second moments of the questionnaire application after surgery, had the lowest score (33.3) in at least 25\% of patients, which may interfere with quality of life. In a study conducted in Rio Grande do Sul ${ }^{(9)}$, with a total of 41 patients, it was shown that role performance is the function that most affects quality of life, since it was found in a lower score (64.61), showing that patients may have difficulty in performing leisure and work activities. In another study, 24 esophagectomy patients were analyzed in which, when comparing the quality of life of the two histological types of esophageal cancer, there was a significant difference in the domain of functional capacity and equality in all other domains ${ }^{(4)}$.

On the other hand, in both groups in this study, one can mention that at least $75 \%$ of the patients in the control and intervention groups at all moments had the highest score (100.0) in cognitive and social functions. It was shown in a study that within the functional scale the highest score is related to cognitive function, with a score of 82.90 , which is related to the ability to concentrate and memorize, followed by social, physical and emotional function ${ }^{(9)}$.

The evaluation of the symptom scales presented by the patients makes it is possible to assess whether they will directly or indirectly influence their quality of life. Loss of appetite, fatigue and insomnia were found to have higher averages than the others, which negatively interfered with the patients' quality of life. Loss of appetite is highlighted as the most frequent symptom or one with the greatest impact on patients' lives. Fatigue was the symptom with the greatest impact on the lives of 148 patients with esophageal cancer and 86 with gastric cancer with statistical significance in the variable loss of appetite in relation to the life cycle, with adults having a higher score than the older ones ${ }^{(9)}$.

In the study that evaluated patients after three months of esophagectomy, it was observed that $18 \%$ of patients had diarrhea ${ }^{(16)}$. In another study, assessing quality of life after esophagectomy, nausea and vomiting had significant improvements after three months of surgery. In this study, it was demonstrated that diarrhea had a score greater than 33.3 in both groups, regardless of the diagnosis in at least $75 \%$ of patients in the postoperative moments. Regarding the symptoms of nausea and vomiting, a higher score (66.7) was observed in at least $75 \%$ of the patients in the control group in the first two post-surgical moments ${ }^{(17)}$.

With regard to the evaluation of the distress thermometer questionnaire, it was found that at least $75 \%$ of patients in both groups, at T1 and T2 moments, had level 6 distress, which can affect the quality of life of these patients. The study by Lera $(2011)^{(11)}$, when analyzing a total of 40 older adults patients with cancer undergoing chemotherapy, obtained an average score of 4.20 , equivalent to high stress (cut greater than or equal to 4), with the total of older adults who had high stress being $65 \%$. The assessment of distress is necessary in view of the population growth of cancer patients, as there is a reduction in the organic capacity to respond to stress, making it increasingly necessary to adopt a broad approach for these patients, so that one can intervene in an adequate way in view of the possible factors related to the occurrence of stress during cancer treatment ${ }^{(18)}$.

Pain is one of the symptoms expected in cancer patients and in the postoperative period, which if not properly treated, can increase mortality ${ }^{(7)}$. In a study carried out in Switzerland, the pain of a total of 12,179 patients in the immediate postoperative period was evaluated, showing that $73 \%$ of the patients had no pain at admission, 23\% mild pain and $4 \%$ severe pain and at the moment of discharge, $87 \%$ had no pain, $13 \%$ mild pain and $0.1 \%$ severe pain, which differs in percentage terms, that is, a lower percentage of pain both at admission and at discharge ${ }^{(7)}$. In this study, it can be seen that most patients in the control group reported absence of pain in the preoperative period ( $75 \%$ in the control group and $85.4 \%$ of the patients in the intervention group), as well as in the postoperative period at T2, T3 and T4. In addition, it can also be observed in this study that the percentage of pain in relation to its absence in the postoperative moments was lower than in the preoperative period.

Another factor evaluated in this study was the patients' visit to CAIO, with no significant difference between the groups. The visits to CAIO showed that it did not comprise necessarily a problem related to surgical treatment, since most requests for inter-consultation were not directed to the surgical team. On the other hand, most patients did not remain hospitalized, which indicates that the visits could be non-urgent symptoms that could be resolved via outpatient care or by telephone. It was observed in a study that the intervention group, when compared to the control group, showed a reduction in the demand for health services, using 
fewer resources in the post-operative period of prostatectomy, reducing the number of readmissions and, consequently, generating savings for the health sector ${ }^{(19)}$. Studies show the role of health professionals as facilitators of learning, awakening in patients the autonomy and skill necessary to manage their own health care ${ }^{(20)}$. Telephone follow-up can be a facilitating tool in health education due to its flexibility. Thus, the nurses' practice associated with monitoring can produce significant changes in the ability to adjust to the new health condition, highlighting the importance of technical and clinical knowledge of the nurses' interventions, with this monitoring being carried out in several sectors.

Oncology is a productive field for the use of telehealth technology, since patients require long periods of care, with careful and consistent monitoring ${ }^{(15)}$. A study showed that postoperative follow-up by telephone, already common in developed countries, can be transposed to Brazil, even within the scope of the Unified Health System - Sistema Unico de Saúde (SUS), due to its low cost and high adherence to treatment, but it is still not widely used for surgical patients ${ }^{(13,21)}$.

Telephone follow-up, in addition to providing information and clarifying patients' questions, increases the satisfaction of those who receive care ${ }^{(21)}$. Thus, a study demonstrated a high patient satisfaction regarding telephone monitoring, making professionals perfect their intervention techniques ${ }^{(22)}$.

In this study, referring to the active monitoring of patients and the one recommended by the hospital (Hello Nurse), there was a greater degree of satisfaction of patients and family members in the intervention group, despite the high degree of satisfaction with the demand service, as shown with the control group. In addition, the quality and satisfaction of the service provided were also higher.

The scientific literature, scarce in relation to interventions, shows results that meet the expectations of patients, suggesting the way in which they identify nursing by telephone to cancer patients undergoing outpatient treatment and also in postoperative care, which makes the comparison of the results obtained difficult. The proper institutional care already established with Hello Nurse and the serious clinical and comorbid conditions of patients with esophageal and stomach cancer, perhaps made it impossible to find different comparative results between the groups studied.

\section{CONCLUSION}

Among the conditions for conducting this research, one can conclude that there was no statistically significant difference between the control and intervention groups regarding symptoms, quality of life, pain and distress, during the follow-up proposed in the pre and postoperative period.

Telephone monitoring did not reduce the number of admissions to the emergency department for patients in the intervention group compared to the control group. Active monitoring provided greater satisfaction for the patients in the intervention group compared to the satisfaction of the control group with Hello Nurse. The telephone approach is thus configured as a strategy for health promotion.

\section{RESUMO}

Objetivo: Avaliar o monitoramento telefônico nos sintomas, qualidade de vida, distress, admissões no centro de emergência e a satisfação do paciente oncológico submetido a esofagectomia e gastrectomia. Método: Estudo randomizado em dois grupos, realizado no Instituto do Câncer do Estado de São Paulo; sendo que o grupo intervenção recebeu o monitoramento telefônico por quatro momentos após a cirurgia, enquanto que o grupo controle recebeu apenas o atendimento institucional. Resultados: Dos 81 pacientes avaliados, o domínio mais afetado na qualidade de vida foi o desempenho de papel. O distress não mostrou diferença entre os grupos e momentos. Em ambos os grupos, as admissões no centro de emergência foram semelhantes $(p=0,539)$. A dor foi o sintoma mais relatado no monitoramento telefônico. Houve significância estatística em relação à satisfação do paciente com o monitoramento $(p=0,002)$. Conclusão: $\mathrm{O}$ monitoramento telefônico proporcionou maior satisfação dos pacientes no grupo intervenção, demonstrando o real impacto desse processo no cuidado do paciente oncológico.

\section{DESCRITORES}

Neoplasias; Gastrectomia; Esofagectomia; Telemonitoramento; Qualidade de Vida; Enfermagem Oncológica.

\section{RESUMEN}

Objetivo: Evaluar el monitoreo telefónico en los síntomas, en la calidad de vida, en el distrés, en las admisiones en el centro de emergencias y en la satisfacción del paciente oncológico sometido a esofagectomía y gastrectomía. Método: Se trata de un estudio aleatorizado en dos grupos, realizado en el Instituto del Cáncer del Estado de São Paulo, en el que el grupo intervención recibió el monitoreo telefónico en cuatro momentos tras la cirugía, mientras que el grupo control recibió solamente la atención institucional. Resultados: De los 81 pacientes evaluados, el dominio más afectado en la calidad de vida fue el desempeño del papel. El distrés no mostró diferencia entre los grupos y los momentos. En ambos grupos, las admisiones en el centro de emergencia eran similares $(p=0,539)$. El dolor era el síntoma más informado en el monitoreo telefónico. Se encontró una significación estadística relacionada con la satisfacción del paciente y el monitoreo $(p=0,002)$. Conclusión: El monitoreo telefónico brindó más satisfacción a los pacientes en el grupo intervención y demostró el impacto real de este proceso en el cuidado del paciente oncológico.

\section{DESCRIPTORES}

Neoplasias; Gastrectomía; Esofagectomía; Telemonitorización; Calidad de Vida; Enfermería Oncológica.

\section{REFERENCES}

1. Chaves EC, Oyama SMR. Abordagem telefônica como estratégia para promoção da saúde. Rev Gaúcha Enferm. 2007;28(2):171-9.

2. Winkeljohn D. Adherence to oral cancer therapies: nursing interventions. ClinJ Oncol Nurs. 2010;14(4):461-6. doi: http://dx.doi. org/10.1590/S0100-69912013000100002 
3. Stamm B, Girardon-Perlini NMO, Pasqualoto AS, Beuter M, Magnago TSBS. Intervenção telefônica para manejo da ansiedade de pacientes oncológicos: ensaio clínico randomizado. Acta Paul Enferm. 2018;31(2):137-43. doi: https://doi.org/10.1590/1982-0194201800021

4. Pereira MR, Lopes LR, Andreollo NA. Qualidade de vida de doentes esofagectomizados: adenocarcinoma versus carcinoma epidermóide. Rev Col Bras. 2013;40(1):3-10. doi: http://dx.doi.org/10.1590/S0100-69912013000100002

5. Nicolissi AC, Sawada NO. Factors that influence the quality of life of patients with colon and rectal cancer. Acta Paul Enferm. 2010;23(1):125-30. doi: http://dx.doi.org/10.1590/S0103-21002010000100020

6. Albuquerque KA, Pimenta CAM. Distress of cancer patients: prevalence and associated factors in the opinion of family. Rev Bras Enferm. 2014;67(5):744-51. doi: http://dx.doi.org/10.1590/0034-7167.2014670511

7. Mier AC, Siqueira FD, Pretto CR, Colet CF, Gomes JS, Stumm EMF, et al. Analysis of intensity, sensory and affective aspects of pain of patients in immediate postoperative care. Rev Gaúcha Enferm. 2017;38(2):e62010. doi: http://dx.doi.org/10.1590/19831447.2017.02.62010

8. Ribeiro JP, Pinto C, Santos C. Validation study of the Portuguese version of the QLCC30 V.3. Psic Saúde Doenças. 2008;9(1):89-102.

9. Eberhardt AC, Rosanelli CLSP, Berlezi EM, Kolankiewicz AB, Loro MM, Lins SLB. Profile and quality of life of patients with esophageal and gastric cancers. Rev Enferm UFPE. 2015;9(12):1214-22. doi: http://dx.doi.org/10.5205/reuol.8127-71183-1SM.0912201521

10. Lera AT, Miranda MC, Trevisan LLB, Antonangelo DV, Zanellato RM, Tateyama LTC, et al. Aplicação do instrumento termômetro de estresse em pacientes idosos com câncer: estudo piloto. Rev Bras Clin Med (São Paulo). 2011;9(2):112-6.

11. Pereira LV, Souza FAEF. Mensuração e avaliação da dor pós-operatória: uma breve revisão. Rev Latino Am Enfermagem. 1998;6(3):77-84.

12. Souza FAEF. Dor: o quinto sinal vital. Rev Latino Am Enfermagem. 2002;10(3):446-7. doi: http://dx.doi.org/10.1590/S010411692002000300020

13. Cardozo AS, Santana RF, Rocha ICM, Cassiano KM, Mello TD, Melo UG. Phone follow-ups as a nursing intervention in the surgical recovery of prostatectomized elderly. Rev Enferm UFPE. 2017;11(8):3005-12. doi: http://dx.doi.org/10.5205/reuol.11064-98681-4ED.1108201703

14. Landim CAP, Teixeira CRS, Kusumota L, Travagim DAS, Becker TAC, Balaminut T, et al. O significado do ensino por telefone sobre a insulina para pessoas com diabetes mellitus. Rev Gaúcha Enferm. 2011;32(3):554-60. doi: http://dx.doi.org/10.1590/S1983-14472011000300017

15. Sousa RM, Espírito Santo FH, Pinheiro FM. Phone follow-up of onco-hematology patients post-discharge: integrating review of literature. Rev Enferm Centro Oeste Mineiro. 2017;7:e1824. doi: http://dx.doi.org/10.19175/recom.v7i0.1824

16. Finley RJ, Lamy A; Clifton J, Evans KG, Fradet G, Nelems B. Gastrointestinal function following esophagectomy for malignancy. Am J Surg. 1995;169(5):471-5. doi: 10.1016/s0002-9610(99)80197-4

17. Gradauskas P, Rubikas R, Saferis V. Changes in quality of life after esophageal resection for carcinoma. Medicine (Kaunas). 2006;42(3):187-94.

18. Balducci L, Ershler WB. Cancer and ageing: a nexus at several levels. Nat Rev Cancer. 2005;5(8):655-62. doi: 10.1038/nrc1675

19. Mata LRF, Silva AC, Pereira MG, Carvalho EC. Telephone follow-up of patients after radical prostatectomy: a systematic review. Rev Latino Am Enfermagem. 2014;22(2):337-45. doi: http://dx.doi.org/10.1590/0104-1169.3314.2421

20. Pereira DA, Costa NMSC, Sousa ALM, Jardim PCBV, Zanini CRO. The effect of education intervention on the disease knowledge of diabetes mellitus patients. Rev Latino Am Enfermagem. 2012;20(3):478-85. doi: http://dx.doi.org/10.1590/S010411692012000300008

21. Delphino TM, Souza PA, Santana RF. Telemonitoring as intervention in the postoperative facectomy: systematic review of the literature. Rev Min Enferm. 2016;20:e937. doi: http://dx.doi.org/10.5935/1415-2762.20160007

22. Olivatto GM, Teixeira CRS, Pereira MCA, Becker TAC, Hodniki PP, Istilli PT. ATEMDIMEL. Apoio telefônico para o monitoramento em diabetes mellitus tipo 2: expectativas e satisfação dos pacientes. Rev Elet Gestão Saúde. 2015;6(2):15881600. doi: http://dx.doi. org/10.18673/gs.v6i2.22487 